\title{
Influence of Community Participation on Community Ownership of Donor Funded Projects: A Case of Saidia, Samburu County, Kenya
}

\author{
Lelegwe Ltumbesi Steve \\ Department of Education and External Studies, University of Nairobi, Nairobi, Kenya
}

Email address:

slelegwe@gmail.com (L. L. Steve)

To cite this article:

Lelegwe Ltumbesi Steve. Influence of Community Participation on Community Ownership of Donor Funded Projects: A Case of Saidia, Samburu County, Kenya. Humanities and Social Sciences. Vol. 3, No. 5, 2015, pp. 193-200. doi: 10.11648/j.hss.20150305.15

\begin{abstract}
This study was conducted to establish the influence of community participation of community ownership of donor funded projects. The respondents in the study were the randomly chosen trained beneficiaries of Health, ECD and WASH projects of SAIDIA in the Samburu County. A survey and observation methodology was used to collect the research data. Using a combination of survey and descriptive research methodologies, and guided by the following objectives: to establish how community participation influences community ownership of donor funded projects. The findings revealed that there was low level of resource commitment in terms of time and physical resources, low levels of community participation in SAIDIA projects and poor mobilization and awareness strategy. The study recommends that donor funded projects should improve their mobilization and awareness strategies for better community ownership of such projects, donor funded projects should encourage the community to commit their time and physical resources, and finally donor funded projects should embrace high community participation at all levels of project implementation.
\end{abstract}

Keywords: Community Participation, Community Ownership, Donor Funded Projects

\section{Introduction}

\subsection{Background of Study}

Samburu County is an administrative county in the former Rift Valley Province; it borders Laisamis district to the East and North east, Isiolo to the South east, Laikipia North to the South, Baringo East to the South west and Turkana South district to the west and North west. (Softkenya, 2012). The County is sparsely populated with a population of 223,947 (Kenya population census, 2009); 80\% of the inhabitants are Samburu who are the main ethnic group while the remaining $20 \%$ is shared among the Turkana, Kikuyu, Meru and the other tribes of Kenya. The County is semiarid and well known all over the country for its contribution to the Livestock Industry majorly the slaughter stock. Majority of the inhabitants are semi-pastoralists who also practice agriculture. Another sector that has potential is the tourism industry since the county lies in the Northern tourism circuit implying that it has potential to be exploited (Softkenya, 2012).

Donor funded projects have been active in the County with more than fifteen NGOs and CBOs already involved in developmental projects. SAIDIA is one NGO in the Samburu County which is community based and has been in operation since 1986 at Lesirikan, a village near Baragoi and other parts of the County. In its Strategic Plan 2008-11, the organization claims that its ethos is founded on a firm belief in integrated and sustainable development and that its direction and focus have been dictated consistently by the needs and requests of the communities themselves. Thus SAIDIA's methodology revolves around the adaptation of traditional practices coupled with the careful introduction of appropriate technology.

SAIDIA's Strategic Plan 2008-11 for development emphasizes community empowerment. Hence, SAIDIA delivers health care and other services to the local community with a long-term objective of establishing a selfsustaining organization that will ultimately be managed solely by the people of Samburu County. The plan was formulated with the full participation of communities, SAIDIA board members, SAIDIA staff and other NGOs. This in-depth process took place over two years. Consultations focused on whether or not SAIDIA's activities and services 
meet the existing needs and expectations. The meetings, workshops, seminars and staff retreat also provided a platform for sharing information and ideas that can be used to improve SAIDIA's work (SAIDIA, 2008).

DFPs in any community play a big role towards the development of that same community that would take the government or its institution ages to develop (Mitchell \& Ashley, 2010). Most of the donor funded projects play an important role in both food security and agricultural development in Africa as a whole. These funds are most of the time, if not always, given by Western donors or international agencies (Djurfeldt, Aryeetey and Isinika, 2011). Noting that donor funding must of necessity be short-lived, the question that begs the mind is on how the community can ensures sustainability and ownership of these projects when the donors eventually leave. The starting point for any community ownership is to realize that the community itself is a very important asset; existing assets are those factors that give the community energy to take action like teaching a community a variety of skills builds up their capacities forming an essential part of ownership (DeFilippis, Fisher \& Shragge, 2010).

According to Sirgy, Phillips, \& Rahtz (2011) when the community is fully engaged it serves to expand the feeling of community ownership of any given project; engagement comes with results and even motivates the participants to put in an extra effort brining in the aspect of talent. The essential to achieving a desired outcome of any community based project is by the active participation of that same community; full participation says Anderson and McFarlane (2010) can only be attained through full participation where the community is included in decisions pertaining to planning and assume some responsibility on implementation.

Community participation plays a role in the societies which include: increasing democracy, combating exclusion of marginalized and disadvantaged population, empowering and mobilizing people plus resources and developing holistic and integrated approaches towards problems which all point to ensuring ownership (Bartholomew et al, 2011). Phillips and Pittman (2009) state that community participation is important for validity of any donor funded project which brings in the ownership aspect. For any donor funded project to succeed, it must link not only planning with action but also the aspect that community stakeholders must demonstrate their ownership in the in the plan (Sirgy, Phillips, \& Rahtz, 2011).

\subsection{Research Objective}

To establish how community participation influence community ownership of donor funded projects in Samburu County.

\subsection{Research Questions}

How community participation influence community ownership of donor funded projects in Samburu County?

\section{Literature Review}

\subsection{Donor Funded Projects}

According Ribeiro (2009), Donor Funded Projects (DFPs) are organizations that are conceived due to the need of development shortcomings and are time bound? The projects are majorly funded by a small budget and sometimes they are set up in a much disorganized structure especially in cases of emergency and relief needs (Coppola, 2011). Donor funded projects reach the communities through various means which include International Financial Institutions (IFIs), United Nations (U.N) Agencies for example the United Nations Development Program (UNDP) provides grants through government and UNDP offices to start up programs, Consultative Groups to Assist the Poorest (CGAP) where funds flow form global headquarters to individual grassroots institutions as grants and finally public philanthropic foundations (Delmon, 2011).

In any donor funded project there is a strategy on financial and economic analyses of the project to determine the viability and contribution it will make to development says Ribeiro (2011) adding that most donors today are considering community ownership of the various projects as an essential ingredient of development. The tension between accountability to donors and accountability to beneficiaries can only be satisfied through community ownership since it comes with empowerment (Igweonu, 2011).

\subsection{Community Participation}

To achieve any desired outcome, research has suggested that the community must be actively involved; stepping in to the community requires an attitude of 'do it with the people' which entails doing things with them not doing things for them or to them (Anderson \& McFarlane, 2010). Anderson and McFarlane (2010) are of the argument that when things are done for people or to people the emotional commitment is limited thus the significance of participatory development. There are various factors that will determine the participation of any given community and they include: Economic level of the community- depending on the scarcity of resources and the unlimited wants of the society, the poorer the community the more they will participate in the donor funded projects since there is vested personal interest resulting eventually to high level of ownership to projects (Boyes \& Melvin, 2010).

Geographical location- the locality of the community whether it be urban or rural will determine the participation level; urban population tend to be more exposed and learn very fast which is the opposite of rural, being slow learners and they tend to look at development projects with a lot of suspicion leading to minimal participation (World Bank, 2010). Socio-cultural and political context- is there effective leadership? Is there a community culture that is open and ready to embrace development? A community that has good leadership and governance always looks out for transparency and honesty; a sense of ownership is brought out since the 
community through empowerment will demand democracy (Stanfield, 2009). Population coverage- depending on the magnitude of any donor funded project, participation is dependent on how well the community is integrated as groups or individual. Project management should ensure that they have a well laid down strategy in case the population coverage grows beyond or is below the expected figure argues Levy and Lemeshow (2011).

The concept of community project ownership is viewed as a basis for project success. The World Bank (2004) defines participation as "a process through which stakeholders' influence and share control over development initiatives, and the decisions and resources which affect them". The concept of community participation originated about 40 years ago from the community development movement of the late colonial era in parts of Africa and Asia. To colonial administrators, community development was a means of improving local welfare, training people in local administration and extending government control through local self-help activities (McCommon, 1993). However, during this era, the policy failed to achieve many of its aims primarily due to the bureaucratic top-down approach adopted by the colonial administrations (McCommon, 1993). Once people are involved in a project in some way, maintaining ongoing commitment can become the next challenge. Action research can be a very useful way of dealing with problems such as this. By working through strategies and evaluating their effectiveness in terms of building and maintaining participation on an ongoing basis, a project team can come up with solutions that work best in the local situation.

But the fact that it is so often used to indicate different things or that it conceals what is often no more than a tokenistic acknowledgment of local preferences, should not in turn mean that it is rejected. Like the concept of sustainable development it is better to see the term ownership as a principle to which organizations and individuals working in development with local people should aspire. Though imperfectly realized, it is an ideal against which practical efforts should be constantly measured. This objective should be realized through a process of empowerment which gives the poor control over their lives and increases their ability to mobilize sufficient development resources. In this endeavor, Thwala (2001) asserts that public participation in the planning and management of developmental projects is crucial to their lasting success. However, communities have had little say in the provision of water and in decisionmaking processes in South Africa. A privileged minority dominates access to water resources while the majority of the population enjoys little or no water security.

\subsection{Participatory Theory of Development}

Participatory theory of development is of the meaning that any community or society has solutions to the problems undermining socioeconomic transformation on one hand hence it places emphasis on creating partnerships and using participatory and people centered approaches to solve problems (Syokau et al, 2010). Participatory development has been embraced by the Government of Kenya as a strategy do empower disadvantaged communities to take control of their own lives through establishing a partnership between donors and the local communities.

Vorhölter (2009) argues that the principles of participatory theory of development are all people centered; commitment to holism, sustainability, capacity building, self-reliance and finally community- driven development. Participatory development is essential for at least two reasons; it gives vitality to the civil society and economy by empowering communities to negotiate with institutions and thus influencing public policy which provide a check to government power and finally it is important since it enhances efficiency, effectiveness and sustainability of development programs (Narayanasamy, 2009).

Participatory development approaches conventional project practice in a more participatory and sensitive manner and is introduced in a predetermined project framework says Tufte and Mefalopulos (2009) stating on further that it is a top down participation in the sense that management of the project defines how, where and when people can participate making it the common practice due to strained resources. Participatory development also in other terms known as popular participation is the process by which people take an active and influential role in decisions that affect their lives (Doll, 2010). The participatory development process many be a difficult and long process but it bring good fruits which include: contribution of local knowledge of activities, yielding of output relevant to perceived needs and a sense of community ownership (Hamilton, 2011).

Participatory development is a natural process where the communities know their needs and must be actively involved in all the stages of development; this can be achieved through empowerment, which is an essential to participatory development; it is enhanced when the projects in which the people participate are based on democratic approach, strengthening the capacity of members to initiate action on their own. It generates the capacity of people generate and influence development in various levels thus community ownership (United Nations Department of Economics and Social Affairs, 2009).

There are two alternative uses of participation; it can be an end in itself or a means to development argues Narayanasamy (2009) she continues that as an end, participation entails empowerment and as a means it leads to efficiency in project management. Participation is indeed a powerful tool that leads to development of policies such as those pertaining to community ownership. Participation in relation to community ownership according to Ife (2009) is of vital importance because of the following reasons: it results to better decisions, people are more likely to implement decisions that they have made rather that those imposed on them, motivation is enhanced during setting up of goals in participatory decision making process and finally participation improves communication and cooperation. 


\subsection{Conceptual Framework}

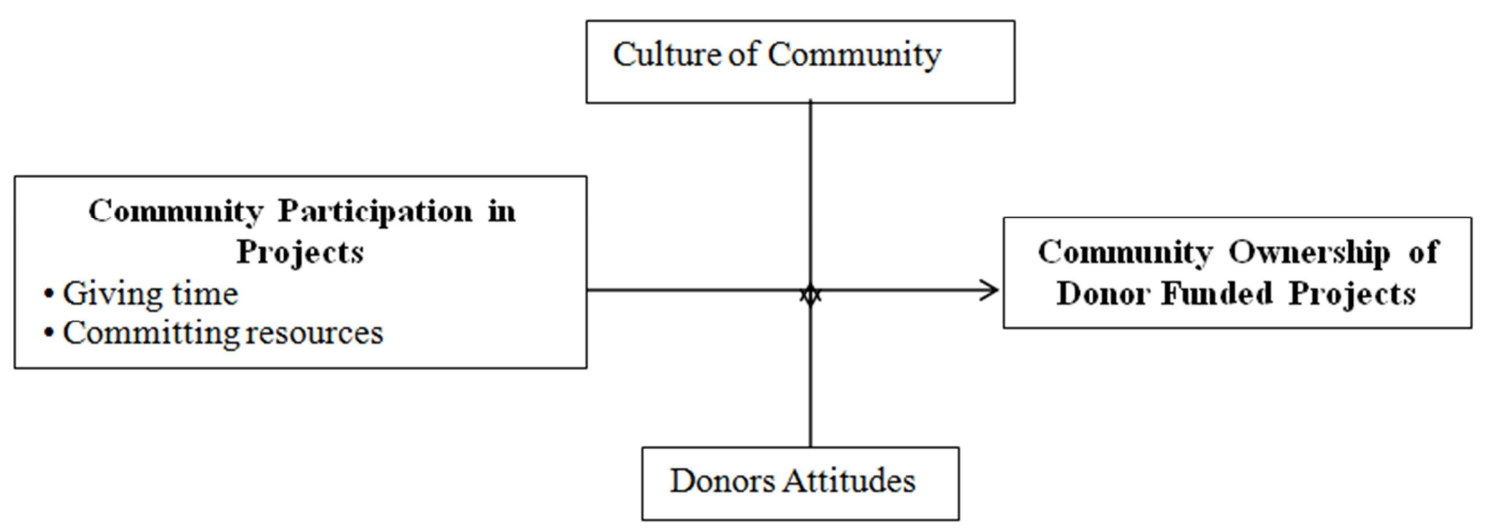

Figure 2.1. Conceptual Framework.

\section{Methodology}

\subsection{Research Design}

Research Design is a plan for collecting and utilizing data so that desired information can be obtained with sufficient precision or so that a hypothesis can be tested properly (Holsti, 1969). This involved developing of research proposal with full complement of data collection tools, discussion with key stakeholders, data collection, entry, analysis, interpretation and reporting. In terms of the design, the study employed survey research design. The study targets beneficiaries of various SAIDIA projects in the Samburu County specifically Health, ECD and WASH. These are the beneficiaries who have undergone some form of training on community participation, project ownership, capacity building and resource mobilization over a period of ten years, which is between 2002 and 2012. The study targets about 2,000 project beneficiaries how have benefited from SAIDIA projects.

\subsection{Sampling Procedure}

Simple random sampling was used in this study, whereby a sample is a group of subjects chosen from a larger group (Cooper 2006). In this case, each subject from the population was chosen randomly and entirely by chance, such that it has the same probability of being chosen at any stage during the sampling process. Only probability samples provide estimates of precision and offer the opportunity to generalize the findings to the population of interest from the sample population (Kothari, 2008). Fisher (1992) recommends 50\% of the target population in social research. According to Mugenda and Mugenda (1999) 10\% of the accessible population is enough for social research study. Therefore $50 \%$ of the target population of Health, ECD and WASH of SAIDIA projects beneficiaries were used, which is 1000 beneficiaries, followed by calculating $10 \%$ of accessible population guided by Gay (1987) sample size Rule of Thump presented in the Table 3.1.
Table 3.1. Population Sample Size.

\begin{tabular}{ll}
\hline Size of population & Sampling percent \\
\hline $0-100$ & $100 \%$ \\
$101-1,000$ & $10 \%$ \\
$1,001-5,000$ & $5 \%$ \\
$5,001-10,000$ & $3 \%$ \\
$10,000+$ & $1 \%$ \\
\hline
\end{tabular}

Table 3.2: gives the sampled population size of the study guided by Gay's theory of Rule of Thumb. One hundred project beneficiaries were selected as shown on Table 3.2.

Table 3.2. Project's Sample Size.

\begin{tabular}{llll}
\hline Gender & $\begin{array}{l}\text { Target } \\
\text { Population }\end{array}$ & $\begin{array}{l}\mathbf{5 0 \%} \text { of Target } \\
\text { Population }\end{array}$ & $\begin{array}{l}\mathbf{1 0 \%} \text { accessible } \\
\text { population/Sample Size }\end{array}$ \\
\hline Men & 800 & 400 & 40 \\
Women & 1200 & 600 & 60 \\
TOTAL & 2000 & 1000 & 100 \\
\hline
\end{tabular}

\subsection{Data Collection, Analysis and Presentation}

Data collection involves gathering both numeric information as well as text information so that both quantitative and qualitative information is captured. Descriptive data was collected through a questionnaire developed by the researcher. This is for the purpose of getting detailed information; it is more impersonal and gives respondents time to collect facts. The research instruments were pre-tested with a group of respondents each from the three projects and who were then excluded from the main interviews.

After administering the questionnaires the researcher coded and the data collected converted was numerical codes for statistical analysis. A Statistical Package for Social Sciences (SPSS) version 17.0 was used for data analysis. Analysis of data employed descriptive statistics such as frequency distributions and percentages. Cross tabulation was run on SPSS to establish correlation between the different variables. The researcher organized the results around the three objectives of the study. The researcher used 
descriptive statistics to show how distribution relationships between variables under study, proportions in term of texts, percentages. The data is presented in Tables preceded by explanations. The result of the sample was generalized to the study population of SAIDIA projects beneficiaries.

\section{Research Findings, Conclusions and Recommendations}

\subsection{Findings}

Influence of community participation on SAIDIA projects was assessed in terms of Time devoted, time allocated to project activities, Participation in the decision committee, commitment of resources, and what resources committed to SAIDIA projects, Community strategy for takeover and willingness to contribute resources after SAIDIA exit.

\subsubsection{Time Devoted to SAIDIA Project Activities per Week}

Table 4.1 indicates time devoted to SAIDIA projects by the respondents per week.

Table 4.1. Time devoted to SAIDIA project activities per week.

\begin{tabular}{lll}
\hline \multicolumn{3}{l}{ Time devoted to SAIDIA project activities per week } \\
\hline & Frequency & Percent \\
\hline 15 and above hours & 1 & 1.0 \\
10-14 hours & 7 & 7.0 \\
5-9 hours & 11 & 11.0 \\
Less than 5 hours & 59 & 59.0 \\
None & 22 & 22.0 \\
Total & 100 & 100.0 \\
\hline
\end{tabular}

The community devotes less time to SAIDIA projects activities with more than $80 \%$ of the respondents devoting less than 5 hours or none at all.

\subsubsection{Reasons for Allocating Time}

Table 4.2 shows the reasons for allocation of time by the respondents on SAIDIA project activities.

Table 4.2. Reasons for allocating time.

\begin{tabular}{lll}
\hline Reasons for allocating time & & \\
\hline & Frequency & Percent \\
\hline Benefits of project to you/community & 60 & 60.0 \\
Resource(s) donated to project & 15 & 15.0 \\
Responsibilities held in project management & 25 & 25.0 \\
Total & 100 & 100.0 \\
\hline
\end{tabular}

In seeking the reasons for allocating time to SAIDIA projects, it was revealed that $60 \%$ respondents allocated time to SAIDIA projects activities based on the benefits obtained from the project. However, $40 \%$ of the respondents allocated time with regard to resources donated to project and responsibility held in project management.

\subsubsection{Participation in the Decision Committee}

Table 4.3 shows participation of respondents in the decision committee of SAIDIA projects.
Table 4.3. Participation in the decision committee.

\begin{tabular}{lll}
\hline Participation in the decision committee & \\
\hline & Frequency & Percent \\
\hline Yes & 25 & 25 \\
No & 75 & 75 \\
Total & 100 & \\
\hline
\end{tabular}

Participation by the community members in decision making was sought in this study, the findings as shown in the Table 4.3 shows that $75 \%$ of the respondents indicated that they do not participate in the decision committees while $25 \%$ said that they participated in the decision committees.

\subsubsection{Commitment of Resources to SAIDIA Projects}

Table 4.4 shows community commitment of resources to SAIDIA projects.

Table 4.4. Commitment of resources to SAIDIA projects.

\begin{tabular}{lll}
\hline \multicolumn{3}{c}{ Commitment of resources to SAIDIA projects } \\
\hline & Frequency & Percent \\
\hline Yes & 24 & 24.0 \\
No & 76 & 76.0 \\
Total & 100 & 100.0 \\
\hline
\end{tabular}

Majority $(76 \%)$ of respondents do not commit any resources to SAIDIA projects while $24 \%$ indicated commitment of resources to SAIDIA projects.

\subsubsection{Resource Committed to SAIDAI Projects}

Table 4.5 shows resource committed to SAIDIA projects by the respondent.

Table 4.5. Resource committed to SAIDIA projects.

\begin{tabular}{|c|c|c|}
\hline \multicolumn{3}{|c|}{ Resource committed to SAIDIA projects } \\
\hline & Frequency & Percent \\
\hline Land & 15 & 15.0 \\
\hline Labour & 63 & 63.0 \\
\hline Time & 12 & 12.0 \\
\hline Money & 6 & 6.0 \\
\hline Protection & 4 & 4.0 \\
\hline Total & 100 & 100.0 \\
\hline
\end{tabular}

About $79 \%$ of respondents did not commit time (labour, time and protection) to the SAIDIA projects with only $21 \%$ committing physical resources to the projects.

\subsubsection{Community Strategy for Takeover of SAIDIA Projects \\ Table 4.6 shows Community strategy for takeover of SAIDIA projects.}

Table 4.6. Community strategy for takeover of SAIDIA projects.

\begin{tabular}{lll}
\hline \multicolumn{3}{l}{ Community strategy for takeover of SAIDIA projects } \\
\hline & Frequency & Percent \\
\hline Community assuming Management & 40 & 40.0 \\
responsibility & 50 & 50.0 \\
Donor Stage phase-out & 10 & 10.0 \\
None & 100 & 100.0 \\
Total & & \\
\hline
\end{tabular}

When asked on the community takeover strategy of SAIDIA projects after their exit, majority (90\%) of 
respondents indicated community assuming management responsibility and donor Stage phase-out while only $10 \%$ indicated none of the above.

\subsubsection{Community Contribute Resources to SAIDIA Projects After Their Exit}

Table 4.7 shows how community contributes resources to SAIDIA projects after their exit.

Table 4.7. Community contribute resources to SAIDIA projects after their exit.

\begin{tabular}{lll}
\hline \multicolumn{3}{c}{ Community contribute resources to SAIDIA projects after their exit } \\
\hline & Frequency & Percent \\
\hline Yes & 13 & 13.0 \\
No & 87 & 87.0 \\
Total & 100 & 100.0 \\
\hline
\end{tabular}

$87 \%$ of respondents indicated they are not ready to contribute resources to SAIDIA projects after their exit.

\subsection{Discussion}

The findings of this study revealed that the level of community participation in SAIDIA projects is low as can be demonstrated by the low resource commitment towards the projects. More so, ownership can be said to be a sense of responsibility with attached expectations on the returns from the projects. However in this context, ownership of donor funded developmental projects means a situation whereby the community will be committed and take responsibility of their own development, put in resources, labour, and time to their developmental projects to ensure sustainability of the same (John Saxby 2003).

The low participation of the community in decision committee, the low commitment of resources to SAIDIA projects and the fact that only fewer than $22 \%$ committed physical resources to SAIDIA projects may mean that the level of community ownership of SAIDIA projects is low as most of the intervention is decided for them and may not necessarily address their immediate need. To achieve any desired outcome, research has suggested that the community must be actively involved; stepping in to the community requires an attitude of 'do it with the people' which entails doing things with them not doing things for them or to them (Anderson \& McFarlane, 2010). The involvement of people in decisions concerning the environment where they live is critical. The concept partly reflects the observation that people who inhabit an environment over time are often the ones most able to make decisions about its sustainable use (Wignaraja, 1991).

\subsection{Conclusion}

From research findings, it was concluded that community participation is key in SAIDIA projects in Samburu County namely, Health; Early Childhood Development (ECD); and Water, Sanitation and Hygiene (WASH) was sought by this study. The study concludes that despite SAIDIA doing community mobilization in Samburu County, there was still low level of participation and ownership of the projects to the extent that the sustainability of the project when they exit is doubtful. There were no emphasis on the project benefits consequently there is no participation and ownership of the project is also doubtful.

The study suggests the following; Donor funded projects should embrace high community participation at all levels of project implementation. Donor funded projects should improve their mobilization and awareness strategies for better community ownership of such projects, donor funded. Lastly, the community should be encouraged to commit time and more physical resources to the SAIDIA projects. Further studies are suggested to establish the factors influencing decision of donors in initiating donor funded projects in communities and to establish the how community involvement in decision making influences ownership of donor funded projects.

\section{References}

[1] Agarwal and Narain (1991) "Towards Green Villages: A strategy For Environmentally Sound and Participatory Rural Development", Centre for Science and Environment, New Delhi.

[2] Anderson, E., \& McFarlane, J. 2010. Community as Partner: Theory and Practice in Nursing $\left(6^{\text {th }}\right.$ ed $)$. New York: Lippincott Williams \& Wilkins.

[3] Bartholomew, L. et al. 2011. Planning Health Promotion Programs: An Intervention Mapping Approach ( $3^{\text {rd }}$ ed.). New Jersey: Wiley \& Sons.

[4] Bell, E. 2010. Research for health policy. Oxford: Oxford University Press.

[5] Block, P. 2009. Community: The Structure of Belonging .California: Berrett-Koehler Publishers.

[6] Boyes, W., \& Melvin, M. 2010. Microeconomics ( $8^{\text {th }}$ ed). Ohio: Cengage Learning.

[7] Cohen, N. 2010. Green Cities: An A-to-Z Guide. Washington DC: SAGE.

[8] Cooper D. Schindler, 2006. Business Research Methods 9Th Ed New York Mcgraw Hill Irwin.

[9] Coppola, D. 2011. Introduction to International Disaster Management $\left(2^{\text {nd }}\right.$ ed.). Burlington: Elsevier.

[10] Danielson, T. J. 2010. Assessing the biological condition of Maine streams and rivers using benthic algal communities. $\mathrm{PhD}$ Dissertation, University of Maine, Orono, Maine.

[11] David Hemson (2003). Sustainability of community water projects in KwaZulu-Natal: Parliamentary Briefing. Human Sciences Research Council.

[12] DeFilippis,. J. Fisher,. R., \& Shragge, E. 2010. Contesting community: the limits and potential of local organizing. New Jersey: Rutgers University Press.

[13] Delmon, J. 2011. Public-Private Partnership Projects in Infrastructure: An Essential Guide for Policy Makers. New York: Cambridge University Press. 
[14] Djurfeldt, G., Aryeetey, E., \& Isinika, A. 2011. African Smallholders: Food Crops, Markets and Policy. Oxforshire: CABI.

[15] Doll, J. 2010. Program development and grant writing in occupational therapy: making the connection. Ontario: Jones $\&$ Bartlett Publishers.

[16] Falk, I., Wallace, R., \& Ndoen, M. 2011. Managing Biosecurity Across Borders. New York: Springer.

[17] Fisher, W. A. (1992). Social research, Newbury Park, CA: Sage.

[18] FRANKEL, R. M.. (2000). Study design in qualitative research: developing research questions and assessing research needs. Education for Health.

[19] GAY, LR 1987. Educational research. Competencies for analysis and application. Third Edition. Columbus. Merrill Publishing Company.

[20] German, L., Ramisch, J., \& Verma, R. 2010. Beyond the Biophysical: Knowledge, Culture, and Power in Agriculture and Natural Resource Management. New York: Springer.

[21] Gofin, J., \& Gofin, R. 2010. Essentials of Global Community Health. London: Jones \& Bartlett Learning.

[22] Hamilton, F. 2011. Goodness to Go.: First Edition Design, March, 7, 2012 from www.firsteditionpublishing.com.

[23] Henderson, P., \& Vercseg, I. 2010. Community development and civil society: making connections in the European context. Bristol: The Policy Press.

[24] Holsti, O., (1969). Content Analysis for Social Sciences and Humanities. Menlo Park, CA: Addison Wesley, 1969.

[25] Ife, J. 2009. Human Rights from Below: Achieving Rights Through Community Development. Cambridge: Cambridge University Press.

[26] Igweonu, K. 2011. Trends in Twenty-First Century African Theatre and Performance. New York: Rodopi.

[27] John, Saxby, 2003. Local ownership and development cooperation - the role of Northern civil society, an issue paper.

[28] Kelly, K., Canada, P., \& Caputo, T. 2011. Community: A Contemporary Analysis of Policies, Programs, and Practices. Toronto: University of Toronto Press.

[29] Kothari, C. 2004. Research methodology: methods and techniques $2^{\text {nd }}$ ed. New Age International. New Age international (p) Ltd.

[30] Levy, P., \& Lemeshow, S. 2011. Sampling of Populations: Methods and Applications ( $4^{\text {th }}$ ed.). New Jersey: Wiley \& Sons.

[31] Mc Common C (1993). Community Management of Rural Water Supply and Sanitation Services; Water and sanitation for Health (WASH) Technical Report. Washington DC: United States Agency for International Aid (USAID). p. 67.

[32] Mclover Chris (2000). Community participation in water management-experiences from Zimbabwe. D+C Development and cooperation. (No,1 January 2000, p.22-24).

[33] Minkler, M. 2011. Community-Based Participatory Research for Health: From Process to Outcomes ( $2^{\text {nd }}$ ed.). New Jersey: Wiley \& Sons.
[34] Mitchell, J., \& Ashley, C. 2010. Tourism and poverty reduction: pathways to prosperity. London: Earthscan.

[35] Morrow, E., et al .2011. Handbook of User Involvement in Nursing and Healthcare Research. New Jersey: Wiley \& Sons.

[36] Mugenda, O. M., \& Mugenda, A. G., (2003). Research Methods - Quantitative and Qualitative Approaches. Nairobi: Acts Press Narayanasamy, N. 2009. Participatory Rural Appraisal: Principles, Methods and Application. New York: SAGE Publications Ltd.

[37] Oakley P. (1991); Projects with people: the Practice of Participation in Rural Development; Geneva, ILO.

[38] OECD. 2005. Paris Declaration on Aid Effectiveness. Paris: OECD Publishing.

[39] Phillips, R., \& Pittman, R. 2009. An Introduction to Community Development. New York: Taylor \& Francis.

[40] Population \& Housing Census Results (2009) presentation by Hon. Wycliffe Ambetsa Oparanya, Minister of State for Planning, National Development and Vision 2030 31st August, 2010; page 23.

[41] Ribeiro, J. 2009. Procurement of Goods, Works and Services in Development Projects. Quebec: Presses inter Polytechnique.

[42] SAIDIA. 2008. SAIDIA Startegic Plan 2008-2011. Retrieved on March, 22 $2^{\text {nd }} 2012$ form http://www.saidiakenya.org/Strategic_plan_final_2008_2011.p df.

[43] Sirgy, M., Phillips, R., \& Rahtz, D. 2011. Community Qualityof-Life Indicators: Best Cases V. New York: Springer.

[44] Softkenya. 2012. Samburu County. Retrieved March, $22^{\text {nd }}$ 2012 from http://softkenya.com/samburu-county/.

[45] Stanfield, A. 2009. Defining Effective Leadership: Lead in Whatever You Do. Oklahoma: Tate Publishing.

[46] Syokau, J., et al, 2010. Participatory development in Kenya. London: Ashgate Publishing, Ltd.

[47] Thwala WD (2007). Employment Creation Through Public Works Programme: New Agenda:, Third Quarter. S. Afri. J. Soc. Econ. Policy, p. 27.

[48] Thwala WDA (2001). Critical Evaluation of Large-Scale Development Projects and Programmes in South Africa 19801994. Msc thesis, University of the Witwatersrand.

[49] Tim, Jackson. 2004: Project development and community expectations, Georgia Institute of Technology.

[50] Tufte, T., \& Mefalopulos, P. 2009. Participatory communication: a practical guide. Washington DC: World Bank Publications.

[51] UNESCO, 1995: Universal Declarationon Bioethics and Human Rights.

[52] UNFPA. 2000. The Program Manager's Monitoring and Evaluation Toolkit. Office of Oversight and Evaluation. New York.

[53] United Nations Department of Economic and Social Affairs. 2009. People matter: civic engagement in public governance. Washington DC: United Nations Publications. 
[54] Vorhölter, J. 2009. Towards a Culture of Participation. Berlin: LIT Verlag Münster.

[55] Wignaraja PA, Hussain A, Sethi H, Wignaraja G (1991). Participatory Development. Oxford: Oxford University Press.

[56] World Bank (1993). World Development Report: Investing in Health. New York: Oxford University Press.
[57] World Bank (2004). World Development Report: Making Services Work for Poor People. Washington DC: World Bank.

[58] World Bank. 2010. World Development Indicators 2010. Washington DC: World Bank Publications. 